\title{
Interdisciplinary Approaches at Institutions of Higher Education: Teaching Information Systems Concepts to Students of Non-Computer Science Programs
}

\author{
doi:10.3991/ijim.v5i3.1670 \\ Roland Schwald \\ Albstadt-Sigmaringen University, Sigmaringen, Germany
}

\begin{abstract}
The aim of this paper is to present a curriculum development concept for teaching information systems content to students enrolled in non-computer science programs by presenting examples from the Business Administration programs at Albstadt-Sigmaringen University, a state university located in Southern Germany. The main focus of this paper therefore is to describe this curriculum development concept. Since this concept involves two disciplines, i.e. business administration and computer science, the author argues that it is necessary to define the roles of one discipline for the other and gives an example on how this could be done.
\end{abstract}

The paper acknowledges that the starting point for the development of a curriculum such as one for a business administration program will be the requirements of the potential employers of the graduates. The paper continues to recommend the assignment of categorized skills and qualifications, such as knowledge, social, methodological, and decision making skills to the different parts of the curricula in question for the development of such a curriculum concept. After the mapping of skills and courses the paper describes how specific information systems can be used in courses, especially those with a specific focus on methodological skills. Two examples from Albstadt-Sigma-ringen University are being given.

At the end of the paper the author explains the implications and limitations of such a concept, especially for programs that build on each other, as is the case for some Bachelor and Master programs. The paper concludes that though some elements of this concept are transferable, it is still necessary that every institution of higher education has to take into consideration its own situation to develop curricula concepts. It provides recommendations what issues every institution should solve for itself.

Index Terms-Business education, enterprise information systems, interdisciplinary approaches, university curriculum development.

\section{INTRODUCTION}

In today`s economic environment, characterized especially by globalization and the digitalization of the economy, hardly any modern higher education program, for example in the field of engineering, life sciences, business or education will be able to offer its students an education completely without computer systems content.

The reasons are obvious: Modern-day computer information systems are ubiquitous at many workplaces. Professionals from many different areas, from, say, architecture to zoology work regularly using all types of computer information systems. In some cases, these non-IT professionals have to be proficient even with the conceptual side of information systems.

As an example, one can take a marketing manager who has to oversee the implementation of an electronicbusiness (e-business) solution, a potentially strategic project for a company. This e-business project may include for example a new or improved online shop or an online marketing system.

Or one can think of the VP (Vice President) Logistics of a manufacturing company. Optimizing his area he may well be using the latest release of a major supply chain management system, for example from a company like Infor or Oracle. With such a system he could improve managing the changing demand cycles in his company, for instance.

Or, as a third example, imagine the CEO (Chief Executive Officer) who is using business intelligence software from - for example - Microstrategy to discover trends and interrelationships in his business. Business intelligence systems attempt to improve a company's business performance based on analysis and making use of information. Gartner, a Stamford, CT based information technology research and advisory company defines business intelligence (BI) as follows: "An inter-active process for exploring and analyzing structured, domain-specific information (often stored in data ware-houses) to discern business trends or patterns, thereby deriving insights and drawing conclusions. The business intelligence process includes communicating findings and effecting change. Domains include customers, suppliers, products, services and competitors." [2]

\section{A. Computer Science at Institutions of Higher Education}

Universities from around the world have realized the importance of IT concepts for students and have included computer information systems content into their curricula. Computer science courses in business administration programs were included in the early 1990s when micro- 
computers became popular. The wide availability of the Internet in the late 1990s saw another wave to include more computer science content in non-computer science curricula [3].

The question that arises here of course is how, especially from a conceptual point of view, this can be managed, i.e., how can the manager of a study program at an institution of higher education proceed in a structured way if he or she wants to adapt the program so that it contains the best possible content for the students.

Of course one - possibly the easiest - option for the program manager would be to take a laissez-faire approach and do nothing at all, i.e., leave information systems out of strategic curriculum planning. However, with this approach, an opportunity to design and / or maintain the curriculum in a way that caters to the interests of their future graduates would be missed.

\section{B. Defining the Roles}

Since the role of information systems can vary from one study program to another, one should reflect on the particular roles information systems play for students and graduates of the specific program in question. Computer information systems is such a comprehensive discipline in science that it is often taught in dedicated schools or departments. Business administration on the other hand is also a very large field. A generic bachelor of business administration program will probably consist at least of the core concepts of the business administration field, such as accounting, finance, operations management, marketing, human resources and so on. Unlike pure computer science programs, the main subject of business administration programs is companies and not information systems and information technology in general. Therefore the main focus is primarily on the application of information systems and not so much on their design and development. Information systems in business administration programs hence become important if they support business administration processes. In other words: information systems can be seen as tools to support the business in general.

In a very first step to develop a curriculum that includes information systems content in a systematic way one will have to define the role of IT in the university program being planned. For a business administration program for instance it therefore might be deemed essential for example that a student understands the value of information systems for companies from a strategic as well as from an operational point of view. Also, they have to understand information management in general. Teaching information systems in business programs must enable students to wisely use enterprise information systems.

One effect that can be observed is that the regular usage of information systems in classes increases the acceptance of IT among business administration students. The more students see how a very large portion of concepts from "non-IT" modules or courses such as Human Resources, Finance and Accounting, Marketing and so on are supported by information technology, the more they understand the importance of information systems for today's (and probably tomorrow's) companies.

I argue that it isn't necessary to include as many information systems into the courses as possible but to rather
TABLE I.

ROLE OF INFORMATION SYSTEMS IN BUSINESS ADMINISTRATION PROGRAMS

\begin{tabular}{|l|l|l|}
\hline Conception & Practice & Job related \\
\hline $\begin{array}{l}\text { - Value of Infor- } \\
\text { mation Systems }\end{array}$ & $\begin{array}{l}\text { - Know how to } \\
\text { model business } \\
\text { processes }\end{array}$ & $\begin{array}{l}\text { Prepare for upcom- } \\
\text { ing internships }\end{array}$ \\
\hline $\begin{array}{l}\text { - Experience com- } \\
\text { plexity of large } \\
\text { enterprise systems }\end{array}$ & $\begin{array}{l}\text { Use enterprise } \\
\text { information systems }\end{array}$ & $\begin{array}{l}\text { - and for the job } \\
\text { market after gradua- } \\
\text { tion }\end{array}$ \\
\hline $\begin{array}{l}\text { - Understand infor- } \\
\text { mation management }\end{array}$ & & \\
\hline
\end{tabular}

introduce relevant types of systems to the students in a coherent, logical manner.

It is also important information systems in university courses prepare students for internships and for the job market in general. Students should experience the complexity of ERP (Enterprise Resource Planning) and other large enterprise systems to distinguish them from other types of information systems. Also, we take the view that one should teach students how to model information flows and business processes, activities that are often necessary to implement large IT systems in organizations.

See also table I for possible roles information systems can play in business administration programs.

\section{Background: Albstadt-Sigmaringen University}

I will base my suggestions for a concept to teach information systems to students of non-computer science programs on the situation of the business administration programs at Albstadt-Sigmaringen University. Though this concept is based on a business administration program, the general approach could be similar for some, possibly many, other programs.

Since the examples in this paper are based on the situation at a specific university I will shortly give some background information about this university so one can better assess the concepts proposed in this document.

Albstadt-Sigmaringen University is a public university in the German federal state of Baden-Württemberg (Southern Germany). It has two campuses, one in the city of Albstadt the other in the town of Sigmaringen. Both cities are about 30 kilometers (19 Miles) apart from each other. The university offers Bachelor and Master level courses in the areas of Engineering, Life Sciences as well as Business and Computer Sciences. Currently (Spring/Summer 2010) the university has around 2.600 enrolled students.

There are two pure Business Administration programs available at Albstadt-Sigmaringen University: A Bachelor of Science and a Master of Science program. Students in the last year of the Bachelor program can choose between three specializations: Marketing, Operations Management, and Financial Controlling. The Master of Science program intentionally has a general management focus; therefore there are no specializations available to graduate students.

Both programs therefore have no specialization in MIS (Management Information Systems) or similar. Teaching information systems thus has to happen primarily within the mandatory courses of the programs.

Another particularity here is that the Bachelor of Science in Business Administration program consists of sev- 
en semesters with the fifth semester being a mandatory internship semester. One ramification is that students should be familiar with some major business information systems before they start their internship. Another particularity is that the Master of Science in Business Administration and Management program is a so-called consecutive Master program, i.e., is a direct continuation of the previous Bachelor program.

\section{CONCEPT}

The basic idea of the concept found at this university's business administration programs are the close integration of the skills and qualifications the students should have upon graduation with the courses being taught and the information systems being used in those courses. The students acquire their skills by participating in courses. Depending on the skills emphasized in a course, information systems may or may not be used for teaching purposes.

An important step during the development of a curriculum in general are identifying the relevant qualifications and skills the Business Administration student should have at the time he or she graduates from university. At Albstadt-Sigmaringen University's Business Administration and Computer Sciences Department they are classified into four core skill areas, especially relevant to the Business Administration programs in question:

\section{A. Methodological skills:}

Business administration students have to acquire problem solving skills. As they will become managers they will have to have excellent troubleshooting as well as systematic problem solving skills in order to be successful. On a more basic level, methodological or "how to do" skills also include knowledge about how something can be done. For example, in the case of teaching information systems to business administration students, this could mean letting Bachelor students complete a standard sales transaction with ERP (Enterprise Resource Planning) systems such as SAP ERP or Microsoft Dynamics NAV. By completing such a standard transaction they learn that a business process needs different resources, documents, and organizational units. They will experience the complexity of large enterprise information systems. Also, they will see what skills employees should have when working with such systems and programs.

Another example for acquiring methodological skills would be solving a business problem such as tax calculations with a spreadsheet tool. The use of Microsoft Excel to solve simple to intermediate business problems in the first semester of the Bachelor of Science in Business Program for example will - amongst others - enhance the students' acceptance of information technology so that it will be easier in subsequent semesters to introduce them to more advanced programs and systems.

\section{B. Knowledge:}

In this context this implies acquiring in-depth, explicit knowledge of relevant subjects, in other words acquiring "hard skills". Unfortunately this often implies learning (and sometimes simply memorizing) facts and information. The providers of such facts are usually experts and other knowledgeable professionals.
However, in a higher education course this also means that students (and lecturers of course) can and should critically analyze those facts and information, even if they come from experts. In the case of information systems, this for example could mean teaching information technology architectures. Students should recognize that there are different ways to design and develop information system structures in a company. The students should understand the advantages and disadvantages of the different types of IT architecture and they should be able to discuss what type of IT architecture is useful for what type of organization for example.

\section{Social skills:}

They include for example the capacity for teamwork, oral presentation skills and interactive skills. At AlbstadtSigmaringen University for example, for the duration of a semester, students have to work on a fictitious information systems project as part of a project team. Recently (Summer Semester 2010), a cooperation agreement with a regional IT company has led to the situation where the students can work on real life IT projects as well. The details of this sub concept of the curriculum design will be presented later in this paper.

\section{Decision-making skills:}

Managers have to make decisions in a wide range of areas. Decision making can take place in a systematic or in a non-systematic way. Systematic decision-making approaches have the advantage of potentially resulting in more sophisticated, well-thought-out decisions.

In the area of information systems, this could for example mean selecting a sales force management system based on previous requirements analysis techniques. As one can infer from figure 1 which shows what areas of skills are emphasized at what level of study in the Bachelor of Science Program at Albstadt-Sigmaringen University, applying decision-making skills makes only sense once one has acquired expertise / knowledge, methodological skills and soft skills. Decision-making skills depend on these other skill types.

Of course there are some other skill areas, such as learning skills, emotional skills, and intercultural skills and so on. However, it appears to be practical and purposeful to have a fairly short list of skill areas. Some of these other skill areas can be in some way included in the

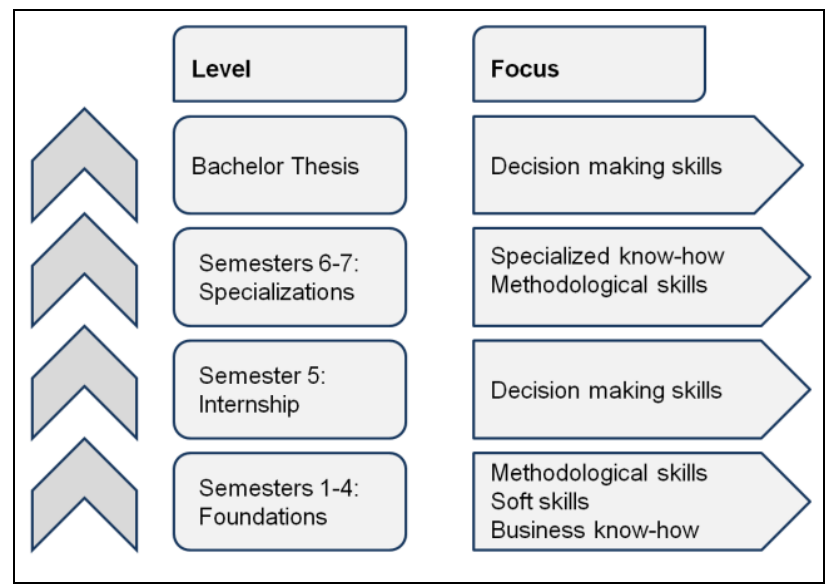

Figure 1. EMPHASIZED SKILL AREAS ON DIFFERENT LEVELS OF THE BACHELOR OF SCIENCE IN BUSINESS PROGRAM 
four skill areas defined here (e.g., intercultural skills or communication skills could both be defined in a way so that they can be included in the social skills area; similarly, critical and analytical thinking skills could be included in the knowledge / hard-skills area); other skills might be only to a lesser degree relevant for business administration graduates.

Though all four relevant skill areas mentioned here have connections to information systems, one can also see that especially when it comes to methodological skills it makes sense to work with actual information systems. Therefore, in the next steps, when we identify the skill areas in the curriculum, we have to have a closer look at courses where methodological skills are in the focus.

Those four core skill areas in reality often overlap. As was stated further above, especially the decision making skills depend on the other forms of skills. For example, a manager who wants to effectively select one information system over the other, he or she has to have at least a general knowledge of the architecture of such systems. In practice, there are often no clear borders between the four core skill areas. Figure 2 illustrates this.

\section{E. Expectations of Potential Employers}

Since these skill areas are indispensable for the development of a curriculum, one has to find out what skills potential future employers of the university's students consider essential. While there seems to be at some institutions a lack of strategic interaction between business schools and the business community [4], this seems to be not a serious problem in the case of Albstadt-Sigmaringen University where there are regular contacts between enterprises and the university where one gets feedback on what skills are demanded from the graduates. Feedback is given for example by internship companies and as well by the advisory board of the Master program that mainly consists of members from the business community.

Also, on the university's supervisory board, there are members from the business world that give valuable feedback regarding what skills are demanded from graduates in the workplace and what the expectations of future employers will be. In addition to that, some visiting lecturers work regularly for local companies and are aware of the skill sets that graduates should possess. Other information sources to see what companies demand from graduates are job advertisements, whether from employment websites, regional and national newspapers, or job openings sent directly to the university.

The university is small enough so that this kind of highly valuable information will be disseminated within the organization and can actually be used.

\section{F. Identifying the Relevant Employers}

The Business Administration programs at AlbstadtSigmaringen University are mainly targeted to the needs of SMEs / SMBs (small and medium enterprises, respectively small and medium sized businesses), especially manufacturing companies in the region surrounding this institution. That does not mean of course that students cannot or will not work for larger companies in the end. However, the focus of the Business Administration programs in question is on educating and preparing future managers of SMEs / SMBs.

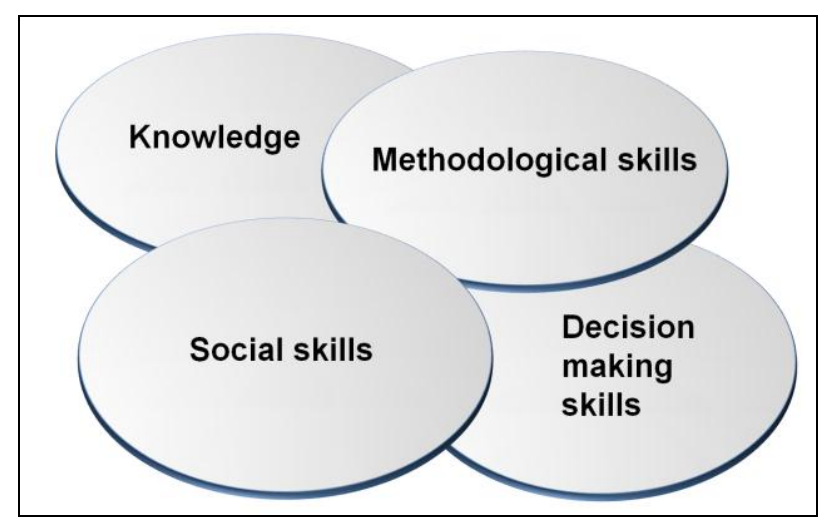

Figure 2. OVERLAPPING OF THE FOUR CORE SKILL AREAS

TABLE II.

COMPARING LARGE COMPANIES WITH SMALL AND MEDIUM-SIZED BUSINESSES

\begin{tabular}{|l|l|}
\hline Large Sized Enterprises & SMBs \\
\hline $\begin{array}{l}\text { Company and brands are } \\
\text { worldwide known. }\end{array}$ & $\begin{array}{l}\text { Company and brands often little } \\
\text { known outside regional markets. }\end{array}$ \\
\hline International production sites. & No or little international exposure. \\
\hline $\begin{array}{l}\text { Many employees with interna- } \\
\text { tional experience. }\end{array}$ & $\begin{array}{l}\text { Few internationally experienced } \\
\text { employees. }\end{array}$ \\
\hline $\begin{array}{l}\text { Access to international finan- } \\
\text { cial markets. }\end{array}$ & $\begin{array}{l}\text { No similar financing options avail- } \\
\text { able. }\end{array}$ \\
\hline $\begin{array}{l}\text { High research and develop- } \\
\text { ment capability. }\end{array}$ & $\begin{array}{l}\text { Often only very specialized re- } \\
\text { search and development. }\end{array}$ \\
\hline $\begin{array}{l}\text { Potential to temporarily offset } \\
\text { losses caused by risky interna- } \\
\text { tional business activities. }\end{array}$ & $\begin{array}{l}\text { Limited potential to spread risks } \\
\text { within the organization. }\end{array}$ \\
\hline
\end{tabular}

It is important to define the type of companies the programs want to address with their graduates because it is a big difference whether one manages a large or a mediumsized company. There are several very general factors that differentiate small and medium-sized businesses from large companies [5].

Apart from having less employees and a smaller revenue base, smaller companies can have several typical characteristics that distinguishes them from large sized companies. For example, sometimes they have a smaller know-how with regard to international markets. They are often more dependent on a small number of large customers. Also, they are typically not that well versed with respect to management techniques and they are often short on financial as well as human resources.

Despite those rather negative characteristics, one can also find some potential advantages a smaller company might have over a bigger company. For example, they often have a production and sales program that is more specialized and therefore suitable to use market niches. Often, the motivation of the employees can be very high, due for instance to the short information and communication channels in these types of companies. Often SMEs / SMBs are more customer friendly and have a higher customer proximity. Smaller organizations are often very flexible compared to larger companies and have a shorter reaction time when it comes to adapt to new challenges. 
TABLE III.

MAPPING SKILLS AND COURSES

\begin{tabular}{|l|l|l|l|}
\hline & $\begin{array}{l}\text { Metho- } \\
\text { dological } \\
\text { skills }\end{array}$ & Know-ledge & $\begin{array}{l}\text { Decision- } \\
\text { makings } \\
\text { skills }\end{array}$ \\
\hline Information Systems I & $\diamond$ & & \\
\hline Internship Preparation & & & \\
\hline Accounting I & & $\diamond$ & \\
\hline Business Statistics & $\diamond$ & & \\
\hline Intro. Business Law & & $\diamond$ & \\
\hline Operations Management & & $\diamond$ & \\
\hline Marketing Seminar & & & \\
\hline Quant. Applic. in Business & $\diamond$ & & \\
\hline Bachelor Thesis & & & \\
\hline$\ldots$ & & & \\
\hline
\end{tabular}

\section{G. Mapping Skills and Courses}

After having defined the role of IT in the Business Administration program under review and if one also has specified what type of companies one targets in the sense that students will primarily seek work there after graduation, then, in the next step of this concept, these skills and qualifications are being mapped with the courses offered for the business administration program in question.

Since there are only two dimensions involved in this step, it is an option to create a simple table highlighting those skills that are particularly important for a specific course.

Table III is an example how such a table can look like. It is based on the Bachelor of Science in Business program at Albstadt-Sigmaringen University. The twodimensional table for the Master of Science in Business and Management program is similarly arranged but also includes a fourth column for "soft skills". In order to keep this paper clear and brief it is not included in this document.

In the case of IT systems used for teaching, especially those courses with a strong focus on methodological skills are identified. In the above example there are three courses that stress methodological skills. In the subsequent step, those courses where it makes particular sense to use information systems are identified.

To better assess what IT / IS content should be allocated to which course one must also have a thorough look at the sequence of the relevant courses identified in the previous step.

Finally, in this concept one investigates possible information systems that could be used in those courses. At the university on which this example is based on, it was for example decided to use Microsoft SQL Server for the Data Analysis course and SAP Business Intelligence for the Data Warehouse course. During the Project Management course for instance, students will work with Microsoft Project Management. Those systems were selected because of their wide usage amongst decision makers.

\section{H. Managing Necessary Resources}

To implement such a concept one needs resources, i.e., human resources, information systems, and available teaching facilities such as computer labs. In the case of Albstadt-Sigmaringen University's Business Administration programs, there are eleven tenured professors, nine non-tenured faculty / staff members, and a number of external lecturers available. Two out of the eleven tenured professor positions have a specific IT focus while five out of the nine non-tenured staff members take care at least to a certain degree of information systems.

Among the problems one might encounter when including concepts from one discipline, such as computer information systems, into a university program of an essentially different discipline, such as business administration, is that there might not be sufficient - with respect to quantity and quality - resources available. The available full-time professors of business administration programs might not be familiar with relevant enterprise information systems. In that case it will be necessary to either create such a position within the department or make use of computer information systems faculty from other departments. However, by using faculty members from other departments it might be that they have only a very technical view of information systems and cannot adapt their teaching style and content to the requirements of a business administration program. The optimum would be to have someone teach computer information systems who has knowledge in both disciplines, i.e., IT and business and has experience teaching business administration students. Lecturers with that type of interdisciplinary skills however are not abundant at smaller universities such as AlbstadtSigmaringen University.

If for whatever reason it is not possible to get adequate help from other departments it is an option to create IT dedicated positions within the business administration department. By offering IT-oriented faculty positions within the business administration department it is at least possible that this will especially attract instructors with an affinity toward business. That type of instructor can be potentially more useful than a pure IT professional with a limited ability to think outside of the box.

One way of working around the possibly arising problem that there might not be enough qualified tenured faculty available is to use scientific coworkers or assistant professors who do the teaching part especially when it comes to offer in-class exercises using real enterprise information systems. Of course this also works only if these staff members on their part are computer literate enough.

\section{EXMAPLES}

The following two examples show how such a concept can be implemented, based on two courses from AlbstadtSigmaringen University.

\section{A. Enterprise Information Systems}

As Bachelor of Business Administration students at Albstadt-Sigmaringen University have to complete a compulsory internship in their $5^{\text {th }}$ semester of studies, it will be of potentially great benefit to them if they had the opportunity to work with modern enterprise information systems beforehand. An often stated optional or mandatory requirement one can read in internship offers is that applicants should have at least a basic knowledge of information systems. Often it is stated in those offers that it would be an advantage for an applicant to be familiar with 
programs such as Microsoft Office but also with larger enterprise information systems such as SAP ERP. However, for internship positions it is normally not the case that applicants are required to have much more than good navigation and general application skills in large enterprise software let alone deep, specialized knowledge in certain system modules such as finance or logistics.

As a typical intern will work with enterprise information systems such as ERP systems or data base management systems, the teaching of that type of systems therefore has to take place before the internship semester. According to the course scheme at Albstadt-Sigmaringen, a course called "Enterprise Information Systems" will take place in the fourth semester of studies, i.e., the semester before the mandatory internship semester. As during the internship semester it will be especially the "to-do" skills, i.e., the methodological skills that come into play, the course "Business Information Systems" (4 $4^{\text {th }}$ semester, Bachelor of Science in Business Program) should have a focus on methodological skills as well.

Since SAP ERP and Microsoft Dynamics NAV are often cited enterprise information systems in job offers and also because students who have completed their internships already often report having worked with those systems during their internships, those two systems were selected to become part of the "Enterprise Information Systems" course. The university has contractual agreements with both companies, i.e., Microsoft and SAP AG. This allows the university to use their systems for either free or at least at educational prices. Apart from the systems themselves, included in those contractual agreements are usually also training material and training for the teaching and research staff.

In this business information systems course, the students get an introduction to both systems. Thereafter they learn how to navigate and complete some simple business processes such as the procurement of material and so on. There are 12 semester hours reserved for exercises with the systems. The maximum group size usually doesn't exceed 25 students. The students have access to the systems for the duration of the semester so that they can do the exercises again at their leisure or explore the systems on their own. There are also staff members available if questions arise.

\section{B. Project Enterprise Software Systems}

In the $7^{\text {th }}$ semester of the curriculum for the Bachelor of Business Administration program appears a course called "Enterprise Software System Project". This course is supported by a regional IT services company that amongst others is a Microsoft partner and offers the ERP system "Microsoft Dynamics NAV." The support of that company consists for one in supplying real projects, i.e., they present actual internal projects such as the development of a new module for an ERP system. The company also provides two of their staff members to facilitate the students' project work, i.e., provide help if the students encounter problems and so on.

The students work in groups of seven to nine persons. The groups each elect a project manager who is responsible for the organizational issues of the project. At the start of the course, the students get an introduction to the business cases they have to solve. They will get some information on how to approach this problem in general, e.g.,
TABLE IV.

IT CURRICULUM AT ALBSTADT-SIGMARINGEN UNIVERSITY

\begin{tabular}{|c|c|c|}
\hline Sem. & Courses with IT content & IT tools / systems used \\
\hline \multicolumn{3}{|c|}{ Bachelor of Science in Business Administration } \\
\hline 1 & $\begin{array}{l}\text { Introduction to Business } \\
\text { Information Systems }\end{array}$ & MS Excel \\
\hline 2 & --- & --- \\
\hline 3 & $\begin{array}{l}\text { Intermediate Business Infor- } \\
\text { mation Systems }\end{array}$ & $\begin{array}{l}\text { MS Approach, SAP BI, } \\
\text { MS Visio etc. }\end{array}$ \\
\hline 4 & $\begin{array}{l}\text { Enterprise Information Sys- } \\
\text { tems }\end{array}$ & $\begin{array}{l}\text { SAP ERP, MS Dynamics } \\
\text { (NAV), ARIS Toolset }\end{array}$ \\
\hline 5 & Internship & Typically various \\
\hline 6 & --- & --- \\
\hline 7 & $\begin{array}{l}\text { Project Enterprise Software } \\
\text { Systems }\end{array}$ & $\begin{array}{l}\text { MS Project, MS Dynamics } \\
\text { (NAV), SAP BI etc. }\end{array}$ \\
\hline \multicolumn{3}{|c|}{ Master of Science in Business Administration and Management } \\
\hline 1 & $\begin{array}{l}\text { Data Warehouse Systems } \\
\text { Data Analysis }\end{array}$ & $\begin{array}{l}\text { MS SQL Server, SAP BI, } \\
\text { Cubeware, Microstrategy }\end{array}$ \\
\hline 2 & E-Business Management & --- \\
\hline 3 & --- & --- \\
\hline
\end{tabular}

they are told to do a market analysis, to define the modules' minimum and maximum functions and so on.

If the project involves an information system the students are not yet familiar with, the functionality of this system will be demonstrated by someone who is in charge of the course and the students will also have the opportunity to do some exercises on the system itself.

At the end of the semester, the student groups present their findings and make recommendations. During the whole semester the external IT staff as well as the professors in charge at the university support the groups and give the groups directions and feedback. The IT services company then decides whether and to what extent they will make use of the projects' outcomes.

A rough overlook of the sequence of the major contents of the mandatory IT courses offered at AlbstadtSigmaringen University is given in the following table [6]:

\section{CONCLUSION}

In this paper I have explained a possible curriculum development approach for teaching information system content to business administration students at a university in Europe, based on an example from AlbstadtSigmaringen University.

While in recent years it has become a matter of discussion whether IT still creates value and adds to the competitiveness of a business [7], the adaptation of non-computer science curricula to include information systems content has progressed and flourished.

An important point for the development of a curriculum are the relevant qualifications and skills the students should have at the time he or she graduates from university, such as methodological skills, a working knowledge of relevant systems, social skills and decision-making skills. A practical approach to teaching business information systems is to accompany lectures with realistic exercises on major information systems. 


\section{A. Benefits of the Concept}

As stated earlier in the text, one option for the business administration program manager would be not to take any action regarding the subject of information systems and technology at all, i.e., to disregard this issue from a conceptual point of view. The consequence of such a nonmanaged approach would be that information systems topics will be more or less randomly instructed, without any prior systematic planning of the IT content. As a result, every instructor in the program teaches information systems at will or - maybe even worse - not at all. In a university program with a high portion of mandatory courses as is the case at Albstadt-Sigmaringen University's Business Administration programs, this will lead to an incoherent study plan. To avoid these problems it therefore makes sense to decide to take a managed, systematic approach.

There are several, however largely intangible benefits to a managed, systematic approach. E.g., in the case of Albstadt-Sigmaringen University, the implementation of the concept took into consideration particularities of the institution and the academic programs concerned. The Business Administration programs are targeted at the needs of future mid-level managers at mid-sized companies / SMBs and the IT content too is geared toward this group. So when entering the job market, the graduates have a fairly good sense of how information systems can help such a business being more successful.

The mapping of skill areas and courses allows identifying modules where the use of information systems is particularly favorable. This will lead to a better, more efficient allocation of resources. Information systems will only be used where they add value to the education of the students. At the same time when it does make sense to use information systems in a specific course, the system used will benefit the learning objectives of the university program.

Also, this method forces the program manager and his or her collaborators in the curriculum planning process to think about the skills and qualifications the graduates should have from a strategic and tactical point of view. By using some sort of matching table to map skills and courses one gets a clear, transparent overview of the distribution of the skill areas within a university program. Done thoroughly, it will lead to a well balanced distribution of the different skill areas over the course of a university program.

To sum it up, with this structured yet flexible enough concept it was possible to systematically drive the curriculum and its content toward the program manager's stated goals.

\section{B. Limitations of the Concept}

On the other hand, there are also some problems this approach could not completely solve. Especially the interface between the undergraduate and the graduate programs is difficult to handle. Though being a consecutive Master program, a considerable number of students have not been enrolled in the previous Bachelor in Business Administration program. Therefore, those students may well have a different skill-set when they start their Master studies at Albstadt-Sigmaringen University than those students who had been enrolled in this university's undergraduate program.

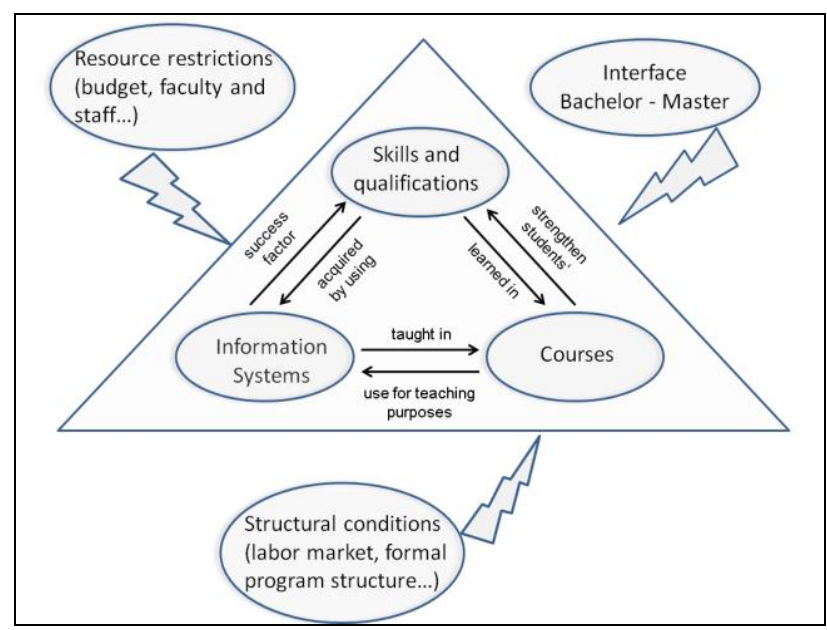

Figure 3. ELEMENTS OF AN INFORMATION SYSTEMS CONCEPT TO BE MANAGED

Another problem is that the IT content is only partially reflected in the study regulations. That means that to some degree the university is dependent on the support of the dean of studies. He or she plays a vital role in the design not only of a curriculum but also how that curriculum is actually filled with content.

And another restriction can be seen in the teaching faculty. If they are not computer-literate, it is difficult to include computer information systems in the courses. One workaround can be for example to use teaching assistants or external lecturers.

In addition to skills and qualifications requirements from potential future employers, designing a curriculum should also consider what competing universities are offering their students. Inferring from discussions with students it becomes clear that they do compare different institutions before deciding to enroll in a specific one. That implies that a university should offer a program that is at least as competitive as those of institutions of higher education one usually competes with for the best talented students. Admission interviews for the Master of Science program often reveal the desire of prospective graduate students to learn more about analytical decision making in organizations for example. For the curriculum that means that business intelligence and similar subjects have to be included in the offering.

An overview of some of the elements of an information systems concept for a non-computer science course is given in figure 3 .

One aspect one can deduce from this figure is that the environment surrounding the university and its relevant programs plays a big role in the development of curriculum concepts.

\section{Recommendations}

Therefore, though this concept theoretically could be adopted by similar universities, one should point out that the curriculum design should certainly take into account the particularities of every individual institution. A mere takeover of concepts, including those presented in this paper, without adapting them to the realities of the relevant institution of higher education will probably not be crowned with success. 
Based on the above analysis, among these particularities that one consequently has to take into account during the curriculum development process are:

- The class sizes and the number of places per computer lab. For courses where one uses software systems there should be enough computers available in a classroom or computer lab so that every student in that class can do the exercises on the system directly. At a typical undergraduate Business Administration course at Albstadt-Sigmaringen University, the number of students attending will be somewhere between 30 and 55. The largest computer lab has 35 workstations; therefore one usually divides one particular semester into two groups, one morning group and one afternoon group.

- The qualifications of the available tenured and nontenured teaching staff. The scale of the planned IT content depends significantly on how many faculty members are available either inside or outside the department, and what their qualifications are.

- The requirements of employers. Starting point for the development of a curriculum in general and the IT content of a university program in particular in the concept presented in this paper are the requirements of potential future employers of the students. If a program manager intends to prepare the students for the relevant job market, he or she should exactly know what qualifications and skills potential employers expect when hiring graduates of that university.

As there are very few publically available documents and other resources on the subject of information systems teaching concepts, I suggest that further research should be carried out in order to assess the effectiveness of various curriculum concepts at universities. One way this could be done is by asking alumni of institutions with different curriculum concepts if and how information systems concepts they have learned during their studies have helped them in their career. One research goal would be to assess the effectiveness of various curriculum concepts. Precondition for this however would be to learn more about the existing curriculum concepts at institutions of higher education. It would be especially helpful if we could learn more about the process how universities in- clude computer information systems in the curricula of non-computer science programs.

\section{REFERENCES}

[1] R. Schwald, "Incorporating Information System Content into NonInformatics Curricula: An Example from a Business Administration Program", in Proceedings of the IABE 2010 Bangkok Summer Conference, vol. 7 (1), G. Savatsomboon, M. D. Gavriletea, Eds. IABE, 2010, pp. 45-49.

[2] Gartner (2010, April 30): Business Intelligence [Online]. Available: http://www.gartner.com/6 help/glossary/GlossaryB.jsp.

[3] F. G. Cauley, F. D. Aiken, and L. K. Whitney, "Technologies Across Our Curriculum: A Study of Technology Integration in the Classroom", J. of Edu. for Business, vol. 85 (2), pp. 114-118, Nov./Dec. 2009. doi:10.1080/08832320903258600

[4] R. K. Plice, B. A. Reinig, "Leveraging Alumni and Business Community Relations to Assess the Information Systems Curriculum", J. of Edu. for Business, vol. 84 (3), pp. 142-150, Jan./Feb. 2009. doi:10.3200/JOEB.84.3.142-150

[5] J. Gutmann, R. Kabst, Internationalisierung im Mittelstand, Wiesbaden, Germany: Gabler, 2000, pp. 10-11.

[6] R. Schwald, "Curriculum Development for Teaching Business Information Systems to Business Administration Students - An Example from a University of Applied Sciences", in Multikonferenz Wirtschaftsinformatik 2010, M. Schumann et al, Eds. Universitätsverlag Göttingen, Göttingen, Germany, 2010, pp. 339-340.

[7] N. G. Carr, "IT Doesn't Matter", Harvard Business Review, vol. 81 (5), pp. 41-49, May 2003.

\section{AUTHOR}

Roland Schwald is a scholar with the Department of Business and Computer Science at Albstadt-Sigmaringen University, Germany. He holds a Bachelor of Science degree in Business Administration with a specialization in Marketing. Also, he earned an MBA degree from the University of Miami at Coral Gables with specializations in Finance and International Business. He has taught courses in systems analysis as well as some others. His main interests are in global enterprise information system management, business education, and international business management. E-mail: Schwald@hs-albsig.de

A different and at the same time shorter version of this paper has been presented at IABE Conference, Bangkok 4 - 6 June, 2010 and was published in the conference proceedings [1]. In addition, this article is an extended version of a paper presented at the Interdisciplinary Conference of AHLiST 2010 Conference, June 2010, Madrid, Spain. Received May 5th, 2011. Published as resubmitted by the author June 9th, 2011. 